\title{
Pioneer Became Railway Magnate
}

\author{
By L. F. ANDrews
}

One of the most active and prominent men in the early days of Polk county and the state was Herbert M. Hoxie, or "Hub," as he was familiarly called by everybody. His father, Benjamin T. Hoxie, came from Vermont, at a very early day and settled at Fairfield, where he opened a tavern, and "Hub" was along. He attended a subscription school, there being no public schools in those days, and also worked as clerk in a store.

When the garrison at Fort Des Moines was abandoned in 1846, and the place opened to settlers, his father came with a stock of dry goods and opened a store in what had been the sutler's storehouse, and there "Hub" assisted as a clerk. He was very quiet and reserved in habit, did not fraternize much with other young fellows at the fort, Guy Ayers being his most chummy friend, and Guy recalls many times when, together, they gathered wild strawberries on the plateau up west of Eighth street, now occupied by the First Methodist church and educational building.

Mr. Hoxie continued in business about three years. In 1847 , he built a large house of huge logs, which stood askew to the streets at Twelfth and Walnut for many years until torn down in 1876. The logs for this house were cut on the bluff north of High street, and when completed, the house was considered the finest one in the county. He became a very prominent and most useful man in the formative period of Fort Des Moines following the discontinuance of the army fort. He was one of the eight who organized the first Methodist class, which was the nucleus of the First Methodist church. Meeting with business reverses, he closed out his affairs and returned to Jefferson county, and soon after, died.

"Hub" remained, and went to live with "Uncle Tom- 
my" Mitchell, the god-father of Polk county. He was wide awake, energetic and manifested such capabilities for business, that "Uncle Tommy," who was extensively in business, put him in charge as manager. That he succeeded is verified by one of the very few references made to himself, in later years, when he said:

I acted as manager for him, his interests being large for those days, and it was my duty to ride over the place and see that the work was done. The only rebuke I ever received from him, a mild one, was for dismounting from my horse and doing some work myself, which I thought was not being done properly. While doing it, he rode up and I could readily see he was displeased, though he said nothing. We rode away, and when out of sight and hearing of the men, he said, "I do not expect you to do the work. It is your duty to see that it is done; that's all."

He lived with "Uncle Tommy" many years, saved his money, traded some, and regularly made remittances to his mother, who was somewhat dependent. As he reached manhood, he took an active part in politics, and as the protege of "Uncle Tommy" became wellknown and popular.

\section{One of First Republicans Elected}

In 1856, when the Republican party was organized, an effort was made to secure some of the county offices, the Democrats up to that time having had control of the political affairs both in the county and state. "Hub" was nominated by the Republicans for clerk of the district court and elected. W .W. Williamson was elected judge of the court and got his commission, but the Democrats contested it and C. J. McFarland, the most notable, if not notorious, person who ever occupied the bench in this or any other state, was seated. The following year came the capitol location contest between the east and west sides of the river, which was the most exciting and bitter fight ever had in the county. Partisan politics was abjured, and "Hub," inspired by love for his old log house and parental home, gave the westsiders his most strenuous efforts and also subscribed $\$ 1,000$ to the fund to secure the location on the west side. 
At the next election, in 1858, "Hub" was reelected, and the Republicans carried the entire county ticket, and since then the Democrats have succeeded in electing but four candidates, and then on purely local issues: Daniel M. Bringolf, for sheriff, in 1871, reelected in 1873; William Lowry, treasurer, in 1873, purely on the ground of personal popularity; George H. Gardner, recorder, in 1887, and C. C. Loomis, sheriff, in 1889.

\section{MANAGED UNDERGROUND RAIIROAD}

In 1857, during the Kansas Free Soil excitement, Hub was one of the managers of the "Underground Railroad" for the transportation of negroes from Missouri to Kansas, and was declared to be an expert as to the best time and route for shipping "fleeces of wool" as he put it.

In 1860, "Hub" was elected secretary of the Republican state central committee, and the same year one of the delegates to the Republican convention at Chicago, which nominated Lincoln for President. He voted with the majority of the committee, five delegates voting from first to last for William $\mathrm{H}$. Seward.

In 1861, he was appointed United States marshal for the district of Iowa. The whole state was in a turbulent condition. The Democrat party, radically opposed to the war, was doing all it could in that direction. Its newspapers were denouncing the president in vigorous terms and urging resistance to enlistments in the army. At the state convention, July 24, 1861, the following resolution was adopted by the Democrats:

Resolved, that our Union was formed for peace and cannot be perpetuated by force of arms, and that a Republican government held together by the sword becomes a military despotism.

As the exigencies of the war increased, and the Union army was suffering from severe losses, the opposition became more vehement and vituperative. Especially was this so with Dennis A. Mahoney, editor of the Dubuque Herald, the leading Democrat paper of the state. So bitter and personal became his diatribes 
against the administration Hoxie was ordered to arrest him, which he did at his home, August 14, and took him to Washington, where he was confined in the old capitol prison for several months.

Henry Clay Dean was the real leader and the most influential promoter of the war opposition. He was a very talented man and fine speaker. He traveled up and down the state organizing societies to discourage and resist enlistments, denouncing the war as an abolition crusade, carried on by the worst and most unscrupulous men in the country for mere mercenary purposes. He also was arrested when on his way to Keosauqua to make a speech, and confined several weeks.

\section{Fight With the "Golden Circle"}

So insidious and powerful was the influence of Dean and his followers, it did seriously affect enlistments for recruiting the depleted regiments in the field, and there was a prospect that a forced draft would be necessary, whereupon a mass meeting was held in Davis county, at which resolutions were adopted, pledging themselves to resist to the death all attempts to draft citizens into the army; that they would resist the coming of free negroes into Iowa-first by lawful means-that failing, will drive them with those who bring them, out of the state, or give them honorable graves.

One of the organizations resulting from Dean's crusade was known as Knights of the Golden Circle, or Sons of Liberty. It was a secret compact, having a grip and password. It was numerically strong, having in Iowa at one time thirty thousand members. It was blatant and vexatious to the government. It also was ready to take up arms at any time opportunity offered. It had a large membership in Polk county, and Hoxie was kept constantly on the alert.

In June, 1864, the Democrat state convention was held in Des Moines. Reports had reached government officials that Knights of the Golden Circle were going to take advantage of the occasion and the crowd 
present to make a raid on the old state house, seize guns and ammunition stored in the basement, wreck the Daily Register office, and release three men who had been drafted and placed under guard in the county jail. Hoxie, satisfied after a reconnaissance of the crowd, that there was foundation for the rumor, quietly selected one hundred athletic, able-bodied members of the Union League, armed and equipped them for whatever might happen, and placed them on guard at the state house, Register office and other places, with instructions that if they had occasion to shoot, to shoot to kill. Occasionally, I meet some of the members of that guard nowadays. The leaders of the state convention, aware of Hoxie's movement, and knowing how he was built, counseled against any outbreak, for, "if you attempt it," said one of them, "you had better first make arrangements for your funeral."

As somewhat indicating the situation then, General Crocker, who was at home on a furlough, writing to General Dodge in the field said, "Hub Hoxie lets on to be very busy, and I suppose he is. He says he has a kind of general supervision of affairs civil and military in the state."

\section{Worked With General Dodge}

At the close of the war, Hoxie joined General Dodge in building the Union Pacific railroad, and they became firm, fast friends. During his connection with that big enterprise, he developed a remarkable ability for railroad construction. When the International \& Great Western railroad was started, he was made general manager. Later he was elected first vice-president of the Missouri Pacific during its construction. Then he went south and gridironed Arkansas, Texas, and Missouri with railroads until he controlled more miles of railway than any man in the United States, and at the same time was a man of great influence, and a potential factor in the civic affairs in that section, which was infested with the land grabbers and desperadoes of all sorts. He possessed great executive ability, and the knife and revolver retired from within 
ten miles of all his land grant roads, leaving an unobstructed opening to the farmer and the home builder.

The severe labor and exposure, day and night, to properly protect the vast property under his charge from the raids of organized vandalism and ruffianism, was even more than his robust, rugged health could withstand. He contracted a disease which terminated in his death in 1886. His body was brought to Des Moines and laid in Woodland cemetery attended by one of the most notable funerals ever held in the city, prominent citizens and railway men from all parts of the country being present.

\section{Esteem From Boone County Old Settlers}

On that occasion the Old Settlers Association of Boone county being in session, expressed their high esteem for the deceased, which also was that of the host of people who knew the patriotic, public-spirited, noble, generous-hearted man, brave as a lion, yet gentle as a child, in the following words:

The pioneers of Boone county send condolence to the family and friends of the lamented dead "Hub" Hoxie, which they cannot express in words. We all knew him, as you did, noble, magnanimous, robust, honest, whole-souled, warm-hearted man. We have partaken of the hospitality of the old Mitchell homestead when "Hub" was chief there, and we have had his volunteer aid with ox teams in getting out of the interminable sloughs and deep snow drifts of the prairie waste, miles away from that ever welcome shelter and home for all who came, whether they had money or not. We also knew him in public life, and have watched his career since manhood, and have been proud of his achievements. Bury him tenderly beside his dead boy, with whom the father's heart was buried in the by-gone days. He was an enduring monument in the hearts of all the survivors of pioneer times. Peace and rest to his ashes.

A column of panegyric would add nothing to the truthful sentiment expressed by the pioneers of Boone county. It was that of everyone who knew him, or of him. Though his vast railroad operations took him entirely away from early Iowa friends and associations, he never forgot them; he was ever loyal to Iowa and to Des Moines; it was his home to the end of his life. 
Copyright of Annals of Iowa is the property of State of Iowa, by \& through the State Historical Society of Iowa and its content may not be copied or emailed to multiple sites or posted to a listserv without the copyright holder's express written permission. However, users may print, download, or email articles for individual use. 